\title{
Pola Jaringan Angkutan Laut Gugusan Pulau dalam Wilayah Kabupaten Pangkajene Kepulauan
}

\author{
Petrus Filippus Latumahina ${ }^{1 *}$, Syamsul Asri ${ }^{1}$, Andi Sitti Chaerunnisa ${ }^{1}$ \\ ${ }^{1}$ Departemen Teknik Perkapalan, Fakultas Teknik, Universitas Hasanuddin \\ Jl. Poros Malino km. 6, Bontomarannu, Kabupaten Gowa, Sulawesi Selatan 92171 \\ Email: pflatumahina@gmail.com
}

DOI: 10.25042/jpe.112019.14

\begin{abstract}
Abstrak
Secara geografis Kabupaten Pangkajene dan Kepulauan terdiri dari daratan dan kepulauan, dengan luas wilayah laut $11.464,44 \mathrm{~km}^{2}$, dengan pulau sebanyak 115 pulau, 73 pulau berpenghuni dan 42 pulau yang tidak berpenghuni. Kondisi tersebut, membutuhkan jaringan transportasi laut yang handal untuk meningkatkan konektivitas antara pusat-pusat pertumbuhan wilayah dengan pusat-pusat pertumbuhan local. Penelitian ini membahas pola pergerakan penumpang, dan rencana pengembangan sistem jaringan transportasi laut di wilayah gugus pulau Kabupaten Pangkajene dan Kepulauan dengan menggunakan metode analisis klasifikasi silang atau analisis kategori untuk mendapatkan pola bangkitan pergerakan, serta metode analisis gravity model untuk menghitung jumlah pergerakan penumpang. Hasil penelitian menunjukkan bahwa, tingginya potensi bangkitan pergerakan penumpang di wilayah kepulauan, namun ketersediaan jaringan dan pelayanan transportasi masih rendah, Diidentifikasi beberapa pulau sebagai pusat perekonomian utama yang berfungsi sebagai pelabuhan hub untuk menghubungkan pulau-pulau di sekitarnya yang berfungsi sebagai feeder antara lain Pelabuhan Balang Lompo dan Pelabuhan Sarappo Lompo di Kecamatan Liukang Tupabbiring; Pulau Gondong Bali dan Pulau Sabutung di Kecamatan Liukang Tupabbiring Utara; Pelabuhan Matalaang, Pelabuhan Sapuka Lompo, dan Pelabuhan Sailus di Kecamatan Liukang Tangayya; serta Pelabuhan Dewakang Lompo, Pelabuhan Kalukalukuang, dan Pelabuhan Pamantawang di Kecamatan Liukang Kalmas.
\end{abstract}

\begin{abstract}
The Pattern of Sea Transportation Network in the Region of Pangkajene and Islands Regency. Geographically, Pangkajene Islands Regency consist of land and islands, with a sea area of 11,464.44 km2, with 115 islands, 73 inhabited islands and 42 uninhabited islands. These conditions require a reliable sea transportation network to improve connectivity between the regional growth centers and the local growth centers. This study discusses the pattern of passenger movements, and plans for developing a sea transportation network system in the island cluster of Pangkajene Islands Regency using the method of cross classification analysis or category analysis to obtain the pattern of trip generation, as well as the gravity model analysis method for calculating the number of passenger movements. The results showed that, the high potential for passenger movement in the islands, but the availability of transportation networks and services is still low, identified several islands as the main economic center that serves as a hub port to connect the surrounding islands that function as feeders, including Balang Port Lompo and Sarappo Lompo Port in Liukang Tupabbiring District; Gondong Island Bali and Sabutung Island in Liukang Tupabbiring Utara District; Matalaang Port, Sapuka Lompo Harbor, and Sailus Harbor in Liukang Tangayya District; and Dewakang Lompo Port, Kalukalukuang Port and Pamantawang Port in Liukang Kalmas District.
\end{abstract}

Kata Kunci: Jaringan pelabuhan, pola jaringan, transportasi laut

\section{Pendahuluan}

Kabupaten Pangkajene dan Kepulauan adalah salah satu kabupaten di Provinsi Sulawesi Selatan, Indonesia dengan Ibukota Pangkajene yang terletak dipesisir Pantai Barat Provinsi Sulawesi Selatan yang berjarak $\pm 60 \mathrm{~km}$ ke arah utara Kota Makassar. Posisi gugusan astronomisnya antara $4^{\circ} 40^{\prime}$ Lintang Selatan sampai $8^{\circ} 00$ Lintang Selatan dan $110^{\circ}$ Bujur Timur $-119^{\circ} 48^{\prime} 67^{\prime}$ 'Bujur Timur. Luas wilayah
Kabupaten Pangkajene Kepulauan 12.362,73 $\mathrm{km}^{2}$ (setelah diadakan analisis Bakosurtanas) [1].

Kabupaten Pangkajene dan Kepulauan merupakan kabupaten yang struktur wilayah terdiri atas 2 bagian utama yang membentuk kabupaten ini, yaitu :

\subsection{Wilayah Daratan}

Secara adminsitrasi wilayah daratan Kabupaten Pangkajene dan Kepulauan mencakup 9 Kecamatan, yaitu : Pangkajene, 
Minasatene, Balocci, Tondong Tallasa, Bongoro, Labakkang, Ma'rang, Segeri, dan Mandalle dengan jumlah desa/kelurahan sebanyak 103. dengan luas wilayah daratan $898,29 \mathrm{~km}^{2}$.

\subsection{Wilayah Kepulauan}

Wilayah kepulauan Kabupaten Pangkajene dan Kepulauan memiliki luas wilayah laut $11.464,44 \mathrm{~km}^{2}$, dengan pulau sebanyak 115 pulau, 73 pulau berpenghuni dan 42 yang tidak berpenghuni. Dengan wilayah administrasi meliputi 4 kecamatan yang membentuk gugusan pulau, antara lain Kecamatan Liukang Tangaya, Liukang Kalmas, Liukang Tupabbiring, Liukang Tupabbiring Utara.

Untuk menunjang perkembangan ekonomi yang baik perlu dicapai keseimbangan antara penyediaan dan permintaan jasa transportasi. Jika penyediaan jasa transportasi lebih kecil dari pada permintaannya, akan terjadi kemacetan arus barang yang akan menimbulkan ketidakstabilan harga di pasar. Sebaliknya, jika penawaran jasa transportasi melebihi permintaannya maka akan timbul persaingan tidak sehat yang akan menyebabkan banyak perusahaan transportasi rugi dan menghentikan kegiatannya, sehingga penawaran jasa transportasi berkurang, selanjutnya menyebabkan ketidaklancaran arus barang dan ketidakstabilan harga di pasar [2].

Untuk menunjang perkembangan ekonomi yang mantap perlu dicapai keseimbangan antara penyediaan dan permintaan jasa angkutan. Jika penyediaan jasa angkutan lebih kecil daripada permintaannya, akan terjadi kemacetan arus barang yang dapat menimbulkan ketidakstabilan harga di pasaran. Sebaliknya, jika penawaran jasa angkutan melebihi permintaannya maka akan timbul persaingan tidak sehat yang akan menyebabkan banyak perusahaan angkutan rugi dan menghentikan kegiatannya, sehingga penawaran jasa angkutan berkurang, selanjutnya menyebabkan ketidaklancaran arus barang dan kegoncangan harga di pasar [3].

Pengangkutan berfungsi sebagai faktor penunjang dan perangsang pembangunan (the promoting sector) dan pemberi jasa (the service sector) bagi perkembangan ekonomi. Fasilitas pengangkutan harus dibangun mendahului proyek-proyek pembangunan lainnya. Perluasan dermaga di pelabuhan didahulukan daripada pembangunan pupuk yang akan dibangun,guna melancarkan pengiriman peralatan pabrik dan bahan baku serta penyaluran hasil produksi ke pasar setelah pabrik beroperasi [4].

Dari gambaran wilayah geografis dan administrasi dibutuhkan dukungan jaringan transportasi laut untuk meningkatkan konektivitas antar pusat-pusat pertumbuhan wilayah dengan pusat-pusat pertumbuhan lokal khususnya yang terdapat di wilayah kepulauan. Dengan terwujudnya konektivitas antara wilayah kepulauan dengan pusat-pusat pertumbuhan dan pusat-pusat pelayanan dapat meningkatkan perekonomian penduduk serta membuka keterisolasian masyarakat di wilayah kepulauan.

Adapun tujuan dari penelitian ini untuk memberi gambaran pola pergerakan penumpang serta menyusun rencana pola jaringan transportasi laut di wilayah kepulauan Kabupaten Pangkajene dan Kepulauan.

\section{Metode Penelitian}

\subsection{Data Penelitian}

Pengambilan data pada penelitian ini dilakukan di 4 kecamatan yang termasuk dalam wilayah gugus pulau Kabupaten Pangkajene dan Kepulauan. Pengumpulan data dan informasi yang diperlukan diperoleh dengan mengutip dokumen atau arsip dari perusahaan atau dari hasil wawancara langsung perorangan. Jenis data yang diperoleh, antara lain :

- Data Primer, yaitu data yang diperoleh dari hasil observasi langsung di lapangan melaui survey dan wawancara menggunakan kuisioner terhadap masyarakat rumah tangga dan instansi yang bersangkutan;

- Data Sekunder, yaitu data yang diperoleh melalui bahan-bahan tertulis dan informasi lain yang erat kaitannya dengan objek penelitian berupa bangkitan dan tarikan pergerakan.

\subsection{Metode Analisis}

Metode Analisis yang digunakan pada penelitian ini adalah analisis kategori (analisis klasifikasi silang) dan analisis gravity model.

\subsubsection{Analisis Kategori/Klasifikasi Silang}

Analisis klasifikasi silang atau analisis kategori didasarkan pada adanya keterkaitan antara terjadinya pergerakan dengan atribut rumah tangga [2]. Metode analisis kategori 
dikembangkan pertama sekali pada The Puget Sound Transportation Study pada tahun 1964.

Metode analisis klasifikasi silang dilakukan dengan mengalokasikan rumah tangga ke dalam setiap kategori sehingga tiap kategori memuat beberapa rumah tangga yang betul - betul sama tingkat karakteristiknya. Kemudian menentukan rata-rata tingkat perjalanan per rumah tangga pada masing-masing kategori dan setelah itu menentukan jumlah perjalanan pada masingmasing kategori dengan cara mengalikan jumlah perjalanan rata-rata per rumah tangga pada kategori yang bersangkutan dengan jumlah rumah tangga hasil perkiraan dan mentotalkannya untuk semua kategori sehingga didapatkan perkiraan jumlah perjalanan yang diproduksi oleh zona pemukiman yang diteliti pada tahun rencana.

Definisi peubah dan spesifikasi model, misalkan $t^{p}(h)$ adalah rata-rata jumlah pergerakan dengan tujuan $p$ (pada periode waktu tertentu), yang dilakukan oleh setiap anggota rumah tangga dari jenis $h$. Jenis rumah tangga ditentukan berdasarkan stratifikasi. Contohnya, klasifikasi silang yang didasarkan pada $m$ ukuran rumah tangga dengan $n$ pemilikan kendaraan akan menghasilkan $m n$ rumah tangga berjenis $h$.

Metode baku untuk menghitung tingkat pertumbuhan untuk setiap sel didapatkan dengan mengalokasikan rumah tangga ke setiap kelompok sel dan menjumlahkannya satu per satu sehingga menghasilkan jumlah pergerakan $T^{p}(h)$, untuk setiap tujuan pergerakan. Jadi, tingkat pertumbuhan $t^{p}(h)$ didapatkan dengan membagi $T^{p}(h)$ dengan jumlah rumah tangga $H(h)$. Dalam bentuk matematika dapat dinyatakan sebagai [5]:

$$
t^{p}(h)=T^{p}(h) / H(h)
$$

Permasalahan utama dalam penggunaan metode ini terletak pada cara menentukan kategori agar sebaran frekuensi dari simpangan baku dapat diminimumkan.

\subsubsection{Analisis Model Gravity (GR)}

Metode sintetis (interaksi spasial) yang paling terkenal dan sering digunakan adalah model gravity (GR) karena sangat sederhana sehingga mudah dimengerti dan digunakan.
Model ini menggunakan konsep gravity yang diperkenalkan oleh Newton pada tahun 1686 yang dikembangkan dari analogi hukum gravitasi. Metode ini berasumsi bahwa ciri bangkitan dan tarikan pergerakan berkaitan dengan beberapa parameter zona asal, misalnya populasi dan nilai sel MAT yang berkaitan juga dengan aksesibilitas (kemudahan) sebagai fungsi jarak, waktu, atau pun biaya. Newton menyatakan bahwa $\left(F_{i d}\right)$ gaya tarik atau tolak antara dua kutub massa berbanding lurus dengan massanya, $m_{i}$ dan $m_{d}$, dan berbanding terbalik kuadratis dengan jarak antara kedua massa tersebut, $d_{i d}^{2}$, yang dapat dinyatakan dengan :

$$
F_{i d}=G \frac{m_{i} m_{d}}{d_{i d}^{2}}
$$

dimana :

$$
\begin{aligned}
& F_{i d} \text { adalah gaya } \\
& G \text { adalah konstanta gravitasi } \\
& m_{i} m_{d} \text { adalah massa } \\
& d_{i d}^{2} \text { adalah jarak }
\end{aligned}
$$

Dalam ilmu geografi, gaya dapat dianggap sebagai pergerakan antara dua daerah; sedangkan massa dapat digantikan dengan peubah seperti populasi atau bangkitan dan tarikan pergerakan; serta jarak, waktu, atau biaya sebagai ukuran aksesibilitas (kemudahan). Jadi, untuk keperluan transportasi, model GR dinyatakan sebagai:

$$
F_{i d}=k \frac{O_{i} O_{d}}{d_{i d}^{2}}
$$

dimana :

$T_{i d}$ adalah Gaya

$k$ adalah konstanta

$O_{i} O_{d}$ adalah bangkitan dan tarikan

$d_{i d}^{2}$ adalah jarak

Model ini mempunyai beberapa hal yang perlu diperhatikan. Dikatakan bahwa pergerakan antara zona asal $i$ dan zona tujuan $d$ berbanding lurus dengan $O_{i}$ dan $D_{d}$ dan berbanding terbalik kuadratis terhadap jarak antara kedua zona tersebut. Jadi, dalam bentuk matematis, model GR dapat dinyatakan sebagai:

$$
T_{i d}=O_{i} \cdot D_{d} \cdot f\left(C_{i d}\right)
$$

dimana :

$T_{i d}$ adalah Pergerakan

$O_{i}$ adalah Bangkitan 
$D_{d}$ adalah Tarikan

$$
f\left(C_{i d}\right) \text { adalah nilai rata-rata jarak }
$$

Walaupun kelihatan realistis, bila diteliti lebih mendalam, Persamaan (3) menghasilkan kenyataan yang membingungkan dan merupakan kesalahan fatal jika digunakan dalam aspek transportasi. Jika salah satu nilai $O_{i}$ dan salah satu nilai $D_{d}$ menjadi dua kali, pergerakan antara kedua zona meningkat empat kali sesuai dengan Persamaan (3); sebenarnya pergerakan diperkirakan meningkat hanya dua kali. Untuk menjawab hal ini, persamaan yang membatasi $T_{i d}$ diperlukan, dan batasan tersebut tidak dapat dipenuhi oleh Persamaan (3).

$$
\sum_{d} T_{i d}=O_{i} \text { dan } \sum_{i} T_{i d}=D_{d}
$$

$O_{i}$ dan $D_{d}$ menyatakan jumlah pergerakan yang berasal dari zona $i$ dan yang berakhir di zona $d$. Oleh karena itu, penjumlahan sel MAT menurut 'baris' menghasilkan total pergerakan yang berasal dari setiap zona, sedangkan penjumlahan menurut 'kolom' menghasilkan total pergerakan yang menuju ke setiap zona. Pengembangan Persamaan (4), dengan batasan Persamaan (5), menghasilkan Persamaan (6) berikut:

$$
T_{i d}=O_{i} \cdot D_{d} \cdot A_{i} \cdot B_{d} \cdot f\left(C_{i d}\right)
$$

Kedua persamaan pembatas (5) dipenuhi jika digunakan konstanta $A_{i}$ dan $B_{d}$, yang terkait dengan setiap zona bangkitan dan tarikan. Konstanta itu disebut faktor penyeimbang.

$$
A_{i}=\frac{1}{\sum_{d}\left(B_{d} D_{d} f_{i d}\right)} \text { dan } B_{d}=\frac{1}{\sum_{i}\left(A_{i} O_{i} f_{i d}\right)}
$$

Hal yang terpenting untuk diketahui adalah $f_{i d}$ harus dianggap sebagai ukuran aksesibilitas (kemudahan) antara zona $i$ dengan zona $\mathrm{d}$. Hyman menyarankan tiga jenis fungsi hambatan yang dapat digunakan dalam model GR :

- $f\left(C_{i d}\right)=C_{i d}^{-\alpha}$ (Fungsi pangkat)

- $f\left(C_{i d}\right)=e^{-\beta C_{i d}}$ (Fungsi Eksponential negatif)

- $f\left(C_{i d}\right)=C_{i d}^{-\alpha} \cdot e^{-\beta C_{i d}}$ (Fungsi tanner)
Seperti telah dijelaskan terdapat 4 jenis model GR yaitu tanpa-batasan (UCGR), denganbatasan-bangkitan (PCGR), dengan-batasantarikan (ACGR), dan dengan- batasan-bangkitantarikan (PACGR). Model PCGR dan ACGR sering disebut model dengan-satu-batasan (SCGR), sedangkan model PACGR disebut model dengan-dua-batasan (DCGR).

Semua batasan ini tertuang dalam Persamaan 6 dan 7 yang merupakan persamaan model GR yang sering digunakan. Penjelasan di atas menunjukkan bahwa model tersebut dapat diturunkan secara heuristik dengan mengikuti analogi hukum gravitasi Newton. Persamaan (6) dan (7) dikenal sebagai model DCGR. Versi lain yang dikenal dengan model SCGR juga dapat dihasilkan. Dengan menetapkan nilai $B_{d}=1$ untuk semua d untuk menghilangkan batasan bangkitan pergerakan $\left(O_{i}\right)$, maka model PCGR bisa dihasilkan.

Selanjutnya, dengan menetapkan nilai $A_{i}=1$ untuk semua $i$ untuk menghilangkan batasan tarikan pergerakan $\left(D_{d}\right)$, maka bentuk model lain akan dihasilkan yang biasa disebut dengan model ACGR. Terakhir, dengan mengabaikan batasan bangkitan dan tarikan, dihasilkan model UCGR.

Model UCGR mempunyai satu batasan, yaitu total pergerakan yang dihasilkan harus sama dengan total pergerakan yang diperkirakan dari tahap bangkitan pergerakan. Model ini bersifat tanpa-batasan, dalam arti bahwa model tidak diharuskan menghasilkan total yang sama dengan total pergerakan dari dan ke setiap zona yang diperkirakan oleh tahap bangkitan pergerakan. Model tersebut dapat dituliskan sebagai :

$$
T_{i d}=O_{i} \cdot D_{d} \cdot A_{i} \cdot B_{d} \cdot f\left(C_{i d}\right)
$$

$A_{i}=1$ untuk seluruh $i$ dan $B_{d}=1$ untuk seluruh $d$.

Sebagai ilustrasi, berikut ini diberikan contoh perhitungan model UCGR. Pertimbangkan daerah kajian dengan 4 zona. Dari hasil tahap bangkitan pergerakan diperkirakan terjadi bangkitan dan tarikan dari setiap zona. Selain itu, terdapat juga informasi mengenai aksesibilitas antarzona yang dapat berupa jarak, waktu tempuh, dan biaya perjalanan antarzona.

Dengan menggunakan Persamaan (6), perkalian berikut dilakukan untuk setiap sel matriks untuk mendapatkan matriks akhir. 


$$
\begin{aligned}
& T_{11}=A_{1} \cdot O_{1} \cdot B_{1} \cdot D_{1} \cdot \exp \left(-\beta C_{11}\right) \\
& T_{12}=A_{1} \cdot O_{1} \cdot B_{2} \cdot D_{1} \cdot \exp \left(-\beta C_{12}\right) \\
& T_{44}=A_{4} \cdot O_{4} \cdot B_{4} \cdot D_{4} \cdot \exp \left(-\beta C_{44}\right)
\end{aligned}
$$

Dalam model PCGR, total pergerakan global hasil bangkitan pergerakan harus sama dengan total pergerakan yang dihasilkan dengan pemodelan; begitu juga, bangkitan pergerakan yang dihasilkan model harus sama dengan hasil bangkitan pergerakan yang diinginkan. Akan tetapi, tarikan pergerakan tidak perlu sama. Untuk jenis ini, model yang digunakan persis sama dengan Persamaan (6), tetapi dengan syarat batas yang berbeda, yaitu:

$B_{d}=1$ untuk seluruh d dan $A_{i}=\frac{1}{\sum_{d}\left(B_{d} D_{d} f_{i d}\right)}$ untuk seluruh $i$.

Dalam model UCGR, nilai $A_{i}=1$ untuk seluruh $i$ dan nilai $B_{d}=1$ untuk seluruh $d$. Akan tetapi, pada model PCGR, konstanta $A_{i}$ dihitung sesuai dengan Persamaan (7) untuk setiap zona tujuan $i$. Konstanta ini memberikan batasan bahwa total 'baris' dari matriks harus sama dengan total 'baris' dari matriks hasil tahap bangkitan pergerakan.

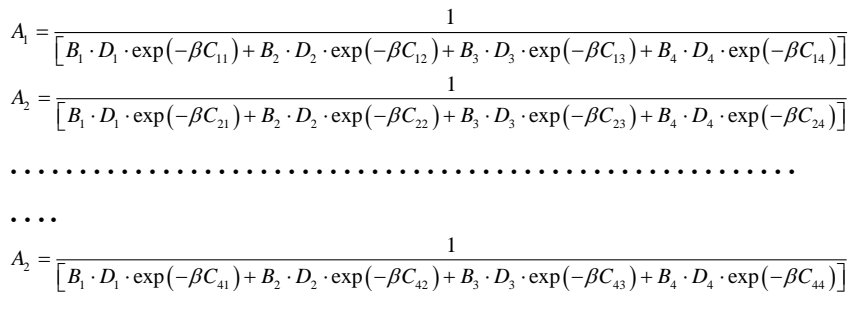

Setelah menghitung nilai $A_{i}$ untuk setiap $i$, setiap sel matriks dapat dihitung dengan menggunakan Persamaan (11) sehingga menghasilkan matriks akhir.

Terlihat bahwa persyaratan awal dipenuhi, yaitu total pergerakan yang dihasilkan model $(t)$ harus sama dengan total pergerakan yang didapat dari hasil bangkitan pergerakan (T). Selain itu, terlihat juga bahwa total pergerakan yang berasal dari setiap zona asal harus selalu sama dengan total pergerakan (yang dibangkitkan) yang diperkirakan oleh tahap bangkitan pergerakan.

Pada model ACGR, total pergerakan secara global harus sama dan juga tarikan pergerakan yang didapat dengan pemodelan harus sama dengan hasil tarikan pergerakan yang diinginkan. Sebaliknya, bangkitan pergerakan yang didapat dengan pemodelan tidak harus sama. Untuk jenis ini, model yang digunakan persis sama dengan Persamaan (11), tetapi dengan syarat batas yang berbeda, yaitu:

$A_{i}=1$ untuk seluruh $i$ dan $B_{d}=\frac{1}{\sum_{i}\left(A_{i} O_{i} f_{i d}\right)}$ untuk seluruh $d$

Dalam model ACGR, konstanta $B_{d}$ dihitung sesuai dengan Persamaan (7) untuk setiap zona tujuan d. Konstanta ini memberikan batasan bahwa total 'kolom' dari matriks harus sama dengan total 'kolom' dari matriks hasil tahap bangkitan pergerakan. Dengan kata lain, total pergerakan hasil pemodelan yang menuju ke suatu zona harus sama dengan total pergerakan hasil bangkitan pergerakan ke zona tersebut.

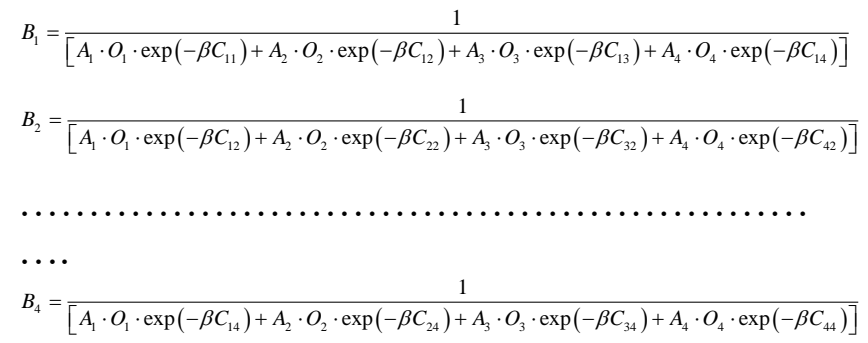

Setelah menghitung nilai $B_{d}$ untuk setiap $d$, setiap sel matriks dapat dihitung dengan menggunakan Persamaan (11) sehingga menghasilkan matriks akhir. Terlihat bahwa selain persyaratan awal dipenuhi, yaitu total pergerakan yang dihasilkan model $(t)$ harus sama dengan total pergerakan yang didapat dari hasil bangkitan pergerakan $(T)$, terlihat juga total pergerakan yang menuju ke setiap zona asal selalu sama dengan total pergerakan (yang tertarik) yang dihasilkan oleh tahap bangkitan pergerakan.

\section{Hasil dan Pembahasan}

\subsection{Gambaran Umum Lokasi}

\subsubsection{Kecamatan Liukang Tupabbiring}

Kecamatan Liukang Tupabbiring memiliki 9 desa/kelurahan pesisir diantaranya Mattiro Deceng, Mattiro Sompe, Mattiro Bone, Mattiro Dolangeng, Mattiro Langi, Mattiro Matae, Mattiro Ujung, Mattiro Adae dan Mattiro Bintang. 
Jumlah penduduk sekecamatan Liukang Tapabbiring tahun 2018 sebanyak 19.259 jiwa dengan kepadatan tertinggi terdapat di Desa Mattiro Sompe yaitu $955 \mathrm{jiwa} / \mathrm{km}^{2}$ yang merupakan wilayah dengan jumlah penduduk terbesar di kecamatan tersebut dan juga merupakan ibukota kecamatan [6].

Di Kecamatan Liukang Tupabbiring sendiri pada tahun 2018 telah tercatat beberapa alat angkut menurut jenisnya seperti kapal motor sebanyak 229 buah, kapal tempel 564 buah, dan perahu tak bermotor sebanyak 307 buah.

\subsubsection{Kecamatan Liukang Tupabbiring Utara}

Pada tahun 2018 jumlah penduduk Kecamatan Liukang Tupabbiring Utara sebanyak 11.546 jiwa dengan kepadatan penduduk 156 jiwa $/ \mathrm{km}^{2}$, dimana kelurahan/desa terpadat adalah Kelurahan Mattiro Bulu. Mayoritas warganya berasal dari suku/etnis Bugis dan Makassar [6].

Di Kecamatan Liukang Tupabbiring Utara sendiri pada tahun 2018 telah tercatat beberapa alat angkut menurut jenisnya seperti kapal motor sebanyak 340 buah, kapal tempel 615 buah, dan perahu tak bermotor sebanyak 126 buah. Selain dipakai untuk sarana trnsportasi antar pulau, perahu juga dipakai oleh para masyarakat untuk menangkap ikan dilaut. Oleh karena itu sarana transportasi (perahu) sangat dibutuhkan bagi masyarakat khususnya masyarakat kepulauan dalam melaksanakan aktifitas sehari-hari dan untuk memenuhi kebutuhan hidup.

\subsubsection{Kecamatan Liukang Kalmas}

Kecamatan Liukang Kalmas terdiri atas 7 desa/kelurahan yaitu Doang-Doangan Lompo, Dewakang, Marasende, Kanyurang, KaluKalukuang, Sebaru, dan Pammas yang merupakan desa pantai dengan luas total 91,50 $\mathrm{km}^{2}$ atau $11,29 \%$ dari luas Kabupaten Pangkajene dan Kepulauan. Berbatasan dengan Kalimantan Selatan di sebelah utara, Kecamatan Liukang Tupabbiring di sebelah timur, Kecamatan Liukang Tangaya di sebelah Selatan dan Kecamatan Jawa Timur di sebelah barat.

Jumlah penduduk Kecamatan Liukang Kalmas pada tahun 2018 mencapai 13.753 jiwa yang terdiri atas 3.276 rumah tangga dengan kepadatan penduduk 150 jiwa per kilometer persegi. Kepadatan penduduk tertinggi terdapat di Kelurahan Pammas dengan kepadatan 280 jiwa $/ \mathrm{km}^{2}$. Dengan jumlah rumah tangga sebanyak 3.276 dari 13.624 penduduk, maka rata-rata satu rumah tangga dihuni oleh 4 anggota rumah tangga. Adapun suku/etnis mayoritas penduduk di Kecamatan Liukang Kalmas adalah berasal dari suku Mandar dan Bugis [7].

Selain itu masyarakat Kecamatan Liukang Kalmas sebagian besar merupakan nelayan penangkap telur ikan terbang dan pengrajin jarring telur ikan. Terdapat 96 unit kapal motor, 738 unit kapal tempel, dan 305 unit perahu tak bermotor yang sebagian besar digunakan untuk melakukan penangkapan ikan dan budidaya rumput laut.

\subsubsection{Kecamatan Liukang Tangaya}

Kecamatan Liukang Tangaya memiliki wilayah seluas $119,6 \mathrm{~km}^{2}$ dan merupakan wilayah kepulauan dengan kurang lebih 50 pulau-pulau besar dan kecil terdiri dari 9 Desa/Kelurahan dan semuanya adalah wilayah pesisir yaitu Desa Sabalana, Balobaloang, Sabaru, Sapuka, Tampaang, Sailus, Satanger, Kapoposan Bali dan Poleonro. Desa Sabalana merupakan desa dengan jumlah pulau terbanyak yaitu 11 pulau dan merupakan desa dengan wilayah terluas.

Jumlah penduduk Kecamatan Liukang Tangayya tahun 2018 sebanyak 22.706 jiwa dengan kepadatan $189 \mathrm{jiwa} / \mathrm{km}^{2}$. Desa dengan kepadatan tertinggi adalah Desa Sapuka 369 jiwa $/ \mathrm{km}^{2}$ mengingat desa tersebut merupakan ibukota kecamatan [8].

Sebagai kecamatan kepulauan, transportasi yang banyak digunakan warga adalah perahu bermotor yang digunakan untuk penyeberangan antar pulau dan untuk menangkap ikan. Tahun 2015 terdapat 466 buah kapal tempel dan 343 buah perahu tak bermotor.

\subsection{Hasil Analisis Data}

\subsubsection{Potensi Pergerakan Muatan di Wilayah} Kepulauan Pangkep

Pada dasarnya pergerakan muatan penumpang maupun barang dari dan menuju daratan Kabupaten Pangkep dipengaruhi oleh kebutuhan primer masyarakat yang bermukim di wilayah kepulauan. Pergerakan penumpang menuju daratan Kabupaten Pangkep bertujuan untuk berbelanja kebutuhan sehari-hari maupun untuk dijual di pulau. Sebaliknya, pergerakan 
penumpang dari daratan Kabupaten Pangkep menuju wilayah kepulauan merupakan penumpang yang kembali setelah berbelanja kebutuhan dan penumpang yang ingin mengunjungi keluarga atau berliburan. Sementara untuk pergerakan barang menuju daratan Kabupaten Pangkep didominasi oleh hasil laut yang dibawa oleh masyarakat untuk dijual. Sebaliknya, pergerakan barang dari daratan Kabupaten Pangkep menuju wilayah kepulauan membawa barang-barang kebutuhan yang dibeli oleh masyarakat.
- Kecamatan Liukang Tupabbiring

Potensi pergerakan penumpang diperoleh dengan melakukan survey pada dua pulau yang merupakan hub pergerakan dalam wilayah ini yaitu Pulau Balang Caddi dan Pulau Balang Lompo. Berdasarkan hasil analisis Kategori, diperoleh bangkitan pergerakan pada kedua pulau tersebut. Untuk bangkitan pergerakan tiap pulau dalam wilayah administrative Kecamatan Liukang Tupabbiring dilakukan dengan pendekatan prosentasi jumlah penduduk dikarenakan keterbatasan waktu survey.

Tabel 1. Potensi bangkitan pergerakan tiap kelurahan di Kecamatan Liukang Tupabbiring

\begin{tabular}{|c|c|c|c|c|c|c|c|c|c|}
\hline No & $\begin{array}{c}\text { Desa / } \\
\text { Kelurahan }\end{array}$ & $\begin{array}{c}\text { Luas } \\
\left(\mathbf{K m}^{2}\right)\end{array}$ & $\begin{array}{c}\text { Jarak Dari } \\
\text { Ibukota } \\
\text { Kecamatan } \\
(\mathbf{k m}) \\
\end{array}$ & $\begin{array}{c}\text { Jarak Dari } \\
\text { Ibukota } \\
\text { Kabupaten } \\
(\text { km) } \\
\end{array}$ & $\begin{array}{l}\text { Jumlah } \\
\text { Rumah } \\
\text { Tangga }\end{array}$ & $\begin{array}{c}\text { Jumlah } \\
\text { Penduduk } \\
\text { (Jiwa) }\end{array}$ & $\begin{array}{l}\text { Kepadatan } \\
\text { Penduduk } \\
(\text { Jiwa/km²) }\end{array}$ & $\begin{array}{c}\text { Potensi } \\
\text { Pergerakan } \\
\text { per bulan }\end{array}$ & $\begin{array}{c}\text { Potensi } \\
\text { Pergerakan } \\
\text { per hari }\end{array}$ \\
\hline 1 & Mattiro Deceng & 9 & 15 & 23 & 629 & 3,379 & 375 & 702 & 23 \\
\hline 2 & Mattiro Sompe & 4.99 & 1 & 20 & 965 & 4,768 & 955 & 991 & 33 \\
\hline 3 & Mattiro Bone & 2.84 & 5 & 24 & 177 & 818 & 288 & 170 & 6 \\
\hline 4 & $\begin{array}{l}\text { Mattiro } \\
\text { Dolangeng }\end{array}$ & 6 & 9 & 20 & 348 & 1,732 & 288 & 360 & 12 \\
\hline 5 & Mattiro Langi & 5 & 15 & 35 & 588 & 2,850 & 570 & 592 & 20 \\
\hline 6 & Mattiro Matae & 10 & 28 & 42 & 287 & 1,820 & 182 & 378 & 13 \\
\hline 7 & Mattiro Ujung & 15 & 38 & 53 & 294 & 1,625 & 108 & 338 & 11 \\
\hline 8 & Mattiro Adae & 4.16 & 5 & 19 & 258 & 1,377 & 331 & 286 & 10 \\
\hline \multirow[t]{2}{*}{9} & Mattiro Bintang & 3.01 & 5 & 21 & 1,072 & 890 & 320 & 185 & 6 \\
\hline & & & & & & & Jumlah & 4.003 & 133 \\
\hline
\end{tabular}

Tabel 2. Potensi bangkitan pergerakan tiap pulau di Kecamatan Liukang Tupabbiring

\begin{tabular}{|c|c|c|c|c|c|c|c|c|c|}
\hline No & Kelurahan & $\begin{array}{c}\text { Jumlah } \\
\text { Penduduk } \\
2018\end{array}$ & Pulau & $\begin{array}{c}\text { Jumlah } \\
\text { Penduduk } \\
\text { Pulau }\end{array}$ & $\begin{array}{c}\text { Jumlah } \\
\text { Penduduk }\end{array}$ & $\begin{array}{c}\text { Perkiraan } \\
\text { Jumlah } \\
\text { Penduduk } \\
\text { Pulau 2018 }\end{array}$ & $\begin{array}{c}\text { Persentasi } \\
\text { Penduduk } \\
\text { Pulau }\end{array}$ & $\begin{array}{c}\text { Potensi } \\
\text { Bangkitan } \\
\text { Pergerakan } \\
\text { per Bulan }\end{array}$ & $\begin{array}{c}\text { Potensi } \\
\text { Bangkitan } \\
\text { Pergerakan } \\
\text { per Hari }\end{array}$ \\
\hline \multirow[t]{2}{*}{1} & \multirow[t]{2}{*}{$\begin{array}{l}\text { Mattiro } \\
\text { Deceng }\end{array}$} & \multirow[t]{2}{*}{3,379} & - Badi & 1,958 & \multirow[t]{2}{*}{3,079} & 2,149 & 0.64 & 447 & 15 \\
\hline & & & - Pajenekang & 1,121 & & 1,230 & 0.36 & 256 & 9 \\
\hline \multirow[t]{4}{*}{2} & \multirow[t]{4}{*}{$\begin{array}{l}\text { Mattiro } \\
\text { Sompe }\end{array}$} & \multirow[t]{4}{*}{4,768} & - Balang Lompo & 2,602 & \multirow[t]{4}{*}{2,743} & 4,523 & 0.95 & 940 & 31 \\
\hline & & & - Balang Caddi & 140 & & 243 & 0.05 & 51 & 2 \\
\hline & & & - Panambungan & - & & - & 0.00 & - & - \\
\hline & & & - Langkadea & 1 & & 2 & 0.0004 & 0 & 0 \\
\hline 3 & $\begin{array}{l}\text { Mattiro } \\
\text { Bone }\end{array}$ & 818 & - Bonto Sua & 1067 & 1067 & 818 & 1.00 & 170 & 6 \\
\hline \multirow[t]{5}{*}{4} & \multirow[t]{5}{*}{$\begin{array}{l}\text { Mattiro } \\
\text { Dolangan }\end{array}$} & \multirow[t]{5}{*}{1,732} & $\begin{array}{l}\text { - Podang- } \\
\text { Podang Lompo }\end{array}$ & 867 & \multirow[t]{5}{*}{1501} & 1,000 & 0.58 & 208 & 7 \\
\hline & & & $\begin{array}{l}\text { - Podang- } \\
\text { Podang Caddi }\end{array}$ & - & & - & 0.00 & 0 & 0 \\
\hline & & & - Lamputtang & 391 & & 451 & 0.26 & 94 & 3 \\
\hline & & & - Pala & 241 & & 278 & 0.16 & 58 & 2 \\
\hline & & & - Cengkeh & 2 & & 2 & 0.0013 & 0 & 0 \\
\hline \multirow[t]{2}{*}{5} & \multirow[t]{2}{*}{$\begin{array}{l}\text { Mattiro } \\
\text { Langi }\end{array}$} & \multirow[t]{2}{*}{2,850} & $\begin{array}{l}\text { - Sarappo } \\
\text { Lompo }\end{array}$ & 1504 & \multirow[t]{2}{*}{2428} & 1,765 & 0.62 & 367 & 12 \\
\hline & & & - Sarappo Keke & 924 & & 1,085 & 0.38 & 225 & 8 \\
\hline
\end{tabular}




\begin{tabular}{|c|c|c|c|c|c|c|c|c|c|}
\hline No & Kelurahan & $\begin{array}{c}\text { Jumlah } \\
\text { Penduduk } \\
2018\end{array}$ & Pulau & $\begin{array}{l}\text { Jumlah } \\
\text { Penduduk } \\
\text { Pulau }\end{array}$ & $\begin{array}{c}\text { Jumlah } \\
\text { Penduduk }\end{array}$ & $\begin{array}{c}\text { Perkiraan } \\
\text { Jumlah } \\
\text { Penduduk } \\
\text { Pulau 2018 }\end{array}$ & $\begin{array}{c}\text { Persentasi } \\
\text { Penduduk } \\
\text { Pulau }\end{array}$ & $\begin{array}{c}\text { Potensi } \\
\text { Bangkitan } \\
\text { Pergerakan } \\
\text { per Bulan }\end{array}$ & $\begin{array}{c}\text { Potensi } \\
\text { Bangkitan } \\
\text { Pergerakan } \\
\text { per Hari }\end{array}$ \\
\hline \multirow[t]{2}{*}{6} & \multirow[t]{2}{*}{$\begin{array}{l}\text { Mattiro } \\
\text { Ujung }\end{array}$} & \multirow[t]{2}{*}{1,625} & - Pandangan & 658 & \multirow[t]{2}{*}{1,119} & 956 & 0.59 & 199 & 7 \\
\hline & & & - Kapoposang & 461 & & 669 & 0.41 & 139 & 5 \\
\hline 7 & $\begin{array}{l}\text { Mattiro } \\
\text { adae }\end{array}$ & 1,377 & - Sanane & 1,032 & 1,032 & 1,377 & 1.00 & 286 & 10 \\
\hline \multirow[t]{2}{*}{8} & \multirow[t]{2}{*}{$\begin{array}{l}\text { Mattiro } \\
\text { Matae }\end{array}$} & \multirow[t]{2}{*}{1,820} & - Gondong Bali & 1,022 & \multirow[t]{2}{*}{1,022} & \multirow[t]{2}{*}{1,820} & \multirow[t]{2}{*}{1.00} & 378 & \multirow[t]{2}{*}{13} \\
\hline & & & $\begin{array}{l}\text { - Saranti } \\
\text { - Tambakulu }\end{array}$ & $\begin{array}{l}- \\
-\end{array}$ & & & & $\begin{array}{l}0 \\
0\end{array}$ & \\
\hline \multirow[t]{2}{*}{9} & $\begin{array}{l}\text { Mattiro } \\
\text { Bintang }\end{array}$ & 890 & & & & & & 185 & 6 \\
\hline & & & & & & & Jumlah & 4,003 & 133 \\
\hline
\end{tabular}

Dari Tabel 1 dan 2 terlihat bahwa potensi pergerakan terbesar tedapat di ibukota Kecamatan yaitu Desa Mattiro Sompe, dimana juga merupakan desa dengan jumlah penduduk terbesar dan tingkat kepadatan penduduk tertinggi. Sedangkan untuk potensi pergerakan tertinggi terdapat di Pulau Balang Lompo yang merupakan lokasi pusat administrative Kecamatan Liukang Tupabbiring.
- Kecamatan Liukang Tupabbiring Utara

Potensi pergerakan penumpang diperoleh dengan melakukan survey pada pulau Sabutung yang merupakan hub pergerakan dalam wilayah ini. Berdasarkan hasil analisis Kategori, diperoleh bangkitan pergerakan pada kedua pulau tersebut. Untuk bangkitan pergerakan tiap pulau dalam wilayah administrasi Kecamatan Liukang Tupabbiring dilakukan dengan pendekatan prosentasi jumlah penduduk dikarenakan keterbatasan waktu survey.

Tabel 3. Potensi bangkitan pergerakan tiap kelurahan di Kecamatan Liukang Tupabbiring Utara

\begin{tabular}{|c|c|c|c|c|c|c|c|}
\hline No. & Desa / Kelurahan & $\begin{array}{c}\text { Luas } \\
\left(\mathbf{k m}^{2}\right)\end{array}$ & $\begin{array}{l}\text { Jumlah } \\
\text { Rumah } \\
\text { Tangga }\end{array}$ & $\begin{array}{c}\text { Jumlah } \\
\text { Penduduk } \\
\text { (jiwa) }\end{array}$ & $\begin{array}{c}\text { Kepadatan } \\
\text { Penduduk } \\
\left(\text { jiwa } / \mathbf{k m}^{2} \text { ) }\right.\end{array}$ & $\begin{array}{c}\text { Potensi } \\
\text { Pergerakan } \\
\text { per bulan }\end{array}$ & $\begin{array}{c}\text { Potensi } \\
\text { Pergerakan } \\
\text { per hari }\end{array}$ \\
\hline 1 & Mattiro Bulu & 3 & 606 & 3,222 & 1,074 & 3,382 & 113 \\
\hline 2 & Mattiro Labangeng & 4 & 179 & 802 & 201 & 842 & 28 \\
\hline 3 & Mattiro Uleng & 5 & 387 & 1,755 & 351 & 1,842 & 61 \\
\hline 4 & Mattiro Kanja & 4.72 & 338 & 1,353 & 287 & 1,420 & 47 \\
\hline 5 & Mattiro Baji & 4.28 & 346 & 1,372 & 321 & 1,440 & 48 \\
\hline 6 & Mattiro Bombang & 22 & 658 & 1,425 & 65 & 1,496 & 50 \\
\hline \multirow[t]{2}{*}{7} & Mattiro Walie & 31 & 402 & 1,617 & 52 & 1,697 & 57 \\
\hline & & & & & & 12,118 & 404 \\
\hline
\end{tabular}

Tabel 4. Potensi bangkitan pergerakan tiap pulau di Kecamatan Liukang Tupabbiring Utara

\begin{tabular}{|c|c|c|c|c|c|c|c|c|c|}
\hline No & Kelurahan & $\begin{array}{c}\text { Jumlah } \\
\text { Penduduk } \\
\mathbf{2 0 1 8}\end{array}$ & Pulau & $\begin{array}{c}\text { Jumlah } \\
\text { Penduduk } \\
\text { Pulau }\end{array}$ & $\begin{array}{c}\text { Jumlah } \\
\text { Penduduk }\end{array}$ & $\begin{array}{l}\text { Perkiraan } \\
\text { Jumlah } \\
\text { Penduduk } \\
\text { Pulau } \\
2018\end{array}$ & $\begin{array}{c}\text { Persentasi } \\
\text { Penduduk } \\
\text { Pulau }\end{array}$ & $\begin{array}{c}\text { Potensi } \\
\text { Bangkitan } \\
\text { Pergerakan } \\
\text { Per Bulan }\end{array}$ & $\begin{array}{c}\text { Potensi } \\
\text { Bangkitan } \\
\text { Pergerakan } \\
\text { Per Hari }\end{array}$ \\
\hline 1 & $\begin{array}{l}\text { Mattiro } \\
\text { Bulu }\end{array}$ & 3,222 & Karanrang & 2,248 & 2,248 & 3,222 & 1.00 & 3,382 & 113 \\
\hline \multirow[t]{2}{*}{2} & \multirow[t]{2}{*}{$\begin{array}{l}\text { Mattiro } \\
\text { Labangeng }\end{array}$} & \multirow[t]{2}{*}{802} & Laiya & 866 & \multirow[t]{2}{*}{1,030} & 674 & 0.84 & 708 & 24 \\
\hline & & & Wali & 164 & & 128 & 0.16 & 134 & 4 \\
\hline \multirow[t]{2}{*}{3} & \multirow[t]{2}{*}{$\begin{array}{l}\text { Mattiro } \\
\text { Uleng }\end{array}$} & \multirow[t]{2}{*}{1,755} & Kulambing & 100 & \multirow[t]{2}{*}{938} & 187 & 0.11 & 196 & 7 \\
\hline & & & $\begin{array}{c}\text { Bangko } \\
\text { Bangkoang }\end{array}$ & 838 & & 1,568 & 0.89 & 1,269 & 42 \\
\hline
\end{tabular}




\begin{tabular}{|c|c|c|c|c|c|c|c|c|c|}
\hline No & Kelurahan & $\begin{array}{c}\text { Jumlah } \\
\text { Penduduk } \\
2018\end{array}$ & Pulau & $\begin{array}{l}\text { Jumlah } \\
\text { Penduduk } \\
\text { Pulau }\end{array}$ & $\begin{array}{l}\text { Jumlah } \\
\text { Penduduk }\end{array}$ & $\begin{array}{c}\text { Perkiraan } \\
\text { Jumlah } \\
\text { Penduduk } \\
\text { Pulau } \\
2018\end{array}$ & $\begin{array}{c}\text { Persentasi } \\
\text { Penduduk } \\
\text { Pulau }\end{array}$ & $\begin{array}{c}\text { Potensi } \\
\text { Bangkitan } \\
\text { Pergerakan } \\
\text { Per Bulan }\end{array}$ & $\begin{array}{c}\text { Potensi } \\
\text { Bangkitan } \\
\text { Pergerakan } \\
\text { Per Hari }\end{array}$ \\
\hline 4 & $\begin{array}{l}\text { Mattiro } \\
\text { Kanja }\end{array}$ & 1,353 & Sabutung & 1412 & 1412 & 1,353 & 1.00 & 1420 & 47 \\
\hline \multirow[t]{4}{*}{5} & \multirow[t]{4}{*}{$\begin{array}{l}\text { Mattiro } \\
\text { Baji }\end{array}$} & \multirow[t]{4}{*}{1,372} & Satando & 420 & \multirow[t]{4}{*}{1271} & 453 & 0.33 & 476 & 16 \\
\hline & & & Saugi & 422 & & 456 & 0.33 & 478 & 16 \\
\hline & & & $\begin{array}{l}\text { Camba- } \\
\text { Cambayya }\end{array}$ & 0 & & - & 0.00 & 0 & - \\
\hline & & & Sapuli & 429 & & 463 & 0.34 & 486 & 16 \\
\hline \multirow[t]{5}{*}{6} & \multirow[t]{5}{*}{$\begin{array}{l}\text { Mattiro } \\
\text { Bombang }\end{array}$} & \multirow[t]{5}{*}{1,425} & Salemo & 1,747 & \multirow[t]{5}{*}{2,836} & 878 & 0.62 & 921 & 31 \\
\hline & & & Sakuala & 538 & & 270 & 0.19 & 284 & 9 \\
\hline & & & Sagara & 375 & & 188 & 0.13 & 198 & 7 \\
\hline & & & Sabangko & 176 & & 88 & 0.06 & 93 & 3 \\
\hline & & & $\begin{array}{l}\text { Gusung } \\
\text { Torajae }\end{array}$ & - & & - & 0.00 & - & - \\
\hline \multirow[t]{8}{*}{7} & \multirow[t]{7}{*}{$\begin{array}{l}\text { Mattiro } \\
\text { Walie }\end{array}$} & \multirow[t]{7}{*}{1,617} & $\begin{array}{l}\text { Samatellu } \\
\text { Lompo }\end{array}$ & 1,376 & \multirow[t]{8}{*}{1,901} & 1,170 & 0.72 & 1,228 & 41 \\
\hline & & & $\begin{array}{l}\text { Samatellu } \\
\text { Pe'dda }\end{array}$ & 33 & & 28 & 0.02 & 29 & 1 \\
\hline & & & $\begin{array}{l}\text { Sa,ateluu } \\
\text { Borong }\end{array}$ & 139 & & 118 & 0.07 & 124 & 4 \\
\hline & & & Salebbo & 353 & & 300 & 0.19 & 315 & 11 \\
\hline & & & $\begin{array}{c}\text { Reang- } \\
\text { Reang } \\
\text { Gusung }\end{array}$ & - & & - & 0.00 & - & - \\
\hline & & & $\begin{array}{c}\text { Bano- } \\
\text { Banoang }\end{array}$ & - & & - & 0.00 & - & - \\
\hline & & & $\begin{array}{c}\text { Gusung } \\
\text { Batu Luara }\end{array}$ & - & & - & 0.00 & - & - \\
\hline & & & & & & & Jumlah & 11.741 & 391 \\
\hline
\end{tabular}

- Kecamatan Liukang Kalmas

Potensi pergerakan penumpang diperoleh dengan melakukan survey pada ibukota kecamatan yaitu di Kelurahan Kalu-kalukuang yang merupakan hub pergerakan dalam wilayah ini dengan jumlah responden 101 kepala keluarga.

Tabel 5. Potensi bangkitan pergerakan tiap kelurahan di Kecamatan Liukang Kalmas

\begin{tabular}{llccccccc}
\hline No. & $\begin{array}{c}\text { Desa / } \\
\text { Kelurahan }\end{array}$ & $\begin{array}{c}\text { Luas } \\
\left(\mathbf{k m}^{2}\right)\end{array}$ & $\begin{array}{c}\text { Jarak ke } \\
\text { Ibukota } \\
\text { Kecamatan } \\
\mathbf{( k m )}\end{array}$ & $\begin{array}{c}\text { Jarak ke } \\
\text { Ibukota } \\
\text { Kabupaten } \\
(\mathbf{k m})\end{array}$ & $\begin{array}{c}\text { Jumlah } \\
\text { Penduduk } \\
\text { (jiwa) }\end{array}$ & $\begin{array}{c}\text { Kepadatan } \\
\text { Penduduk } \\
\left.\text { (jiwa/km } \mathbf{k}^{2}\right)\end{array}$ & $\begin{array}{c}\text { Potensi } \\
\text { Pergerakan } \\
\text { per bulan }\end{array}$ & $\begin{array}{c}\text { Potensi } \\
\text { Pergerakan } \\
\text { per hari }\end{array}$ \\
\hline 1 & $\begin{array}{l}\text { Doang- } \\
\text { doangan }\end{array}$ & 10.9 & 27 & 180 & 749 & 69 & 660 & 22 \\
2 & Dewakkang & 10.9 & 99 & 97 & 2,058 & 189 & 1,814 & 60 \\
3 & Marasende & 12.4 & 42 & 130 & 984 & 79 & 868 & 29 \\
4 & Kanyurang & 10.9 & 24 & 182 & 2,573 & 236 & 2,268 & 76 \\
5 & Kalukalukuang & 23.4 & - & 208 & 2,794 & 119 & 2,463 & 82 \\
6 & Sabaru & 11.4 & 83 & 290 & 1,350 & 118 & 1,190 & 40 \\
7 & Pammas & 11.6 & 85 & 293 & 3,245 & 280 & 2,861 & 95 \\
\hline
\end{tabular}


Tabel 6. Potensi bangkitan pergerakan tiap pulau di Kecamatan Liukang Kalmas

\begin{tabular}{|c|c|c|c|c|c|c|c|c|c|}
\hline No & Kelurahan & $\begin{array}{c}\text { Jumlah } \\
\text { Penduduk } \\
2018\end{array}$ & Pulau & $\begin{array}{c}\text { Jumlah } \\
\text { Penduduk } \\
\text { Pulau }\end{array}$ & $\begin{array}{l}\text { Jumlah } \\
\text { Penduduk }\end{array}$ & $\begin{array}{c}\text { Perkiraan } \\
\text { Jumlah } \\
\text { Penduduk } \\
\text { Pulau } \\
2018\end{array}$ & $\begin{array}{l}\text { Persentasi } \\
\text { Penduduk } \\
\text { Pulau }\end{array}$ & $\begin{array}{c}\text { Potensi } \\
\text { Bangkitan } \\
\text { Pergerakan } \\
\text { Per Bulan }\end{array}$ & $\begin{array}{c}\text { Potensi } \\
\text { Bangkitan } \\
\text { Pergerakan } \\
\text { Per Hari }\end{array}$ \\
\hline \multirow[t]{4}{*}{1} & \multirow[t]{4}{*}{$\begin{array}{l}\text { Doang- } \\
\text { doangan }\end{array}$} & \multirow[t]{4}{*}{749} & $\begin{array}{c}\text { Doang-doangan } \\
\text { Lompo }\end{array}$ & 639 & 1.278 & 375 & 0,50 & 330 & 11 \\
\hline & & & $\begin{array}{c}\text { Bangko- } \\
\text { Bangkoang }\end{array}$ & \multirow[t]{3}{*}{639} & & \multirow[t]{3}{*}{375} & 0,50 & \multirow[t]{3}{*}{330} & \multirow[t]{3}{*}{11} \\
\hline & & & Togo-togo I & & & & 0,00 & & \\
\hline & & & Togo-togo II & & & & 0,00 & & \\
\hline \multirow[t]{3}{*}{2} & \multirow[t]{3}{*}{ Dewakkang } & \multirow[t]{3}{*}{2,058} & $\begin{array}{c}\text { Dewakkang } \\
\text { Lompo }\end{array}$ & 1,112 & \multirow[t]{3}{*}{1.495} & 1.531 & 0,74 & 1.350 & 45 \\
\hline & & & Dewakkang Caddi & 300 & & 413 & 0,20 & 364 & 12 \\
\hline & & & Bangkauluang & 83 & & 114 & 0,06 & 101 & 3 \\
\hline 3 & Marasende & 984 & Marasende & 929 & 929 & 984 & 1,00 & 868 & 29 \\
\hline \multirow[t]{3}{*}{4} & \multirow[t]{3}{*}{ Kanyurang } & \multirow[t]{3}{*}{2.573} & $\begin{array}{c}\text { Bangko- } \\
\text { Bangkoang }\end{array}$ & 909 & \multirow[t]{3}{*}{1.898} & 1.232 & 0,48 & 1.086 & 36 \\
\hline & & & Batung-butungan & 303 & & 411 & 0,16 & 362 & 12 \\
\hline & & & Kanyurang Caddi & 686 & & 930 & 0,36 & 820 & 27 \\
\hline 5 & Kalukalukuang & 2.794 & Kalukalukuang & 2058 & 2.058 & 2.794 & 1,00 & 2.463 & 82 \\
\hline 6 & Sabaru & 1.350 & $\begin{array}{c}\text { Sabaru } \\
\text { Pamolikang }\end{array}$ & 891 & 891 & 1.350 & $\begin{array}{l}1,00 \\
0,00\end{array}$ & 1.190 & 40 \\
\hline \multirow[t]{2}{*}{7} & \multirow[t]{2}{*}{ Pammas } & \multirow[t]{2}{*}{3.245} & $\begin{array}{c}\text { Masalima } \\
\text { Saliriang } \\
\text { Pammantauang }\end{array}$ & $\begin{array}{c}2,719 \\
561 \\
1.498 \\
\end{array}$ & \multirow[t]{2}{*}{4.778} & $\begin{array}{c}1.847 \\
381 \\
1.017 \\
\end{array}$ & $\begin{array}{l}0,57 \\
0,12 \\
0,31 \\
\end{array}$ & $\begin{array}{c}1.628 \\
336 \\
897 \\
\end{array}$ & $\begin{array}{l}54 \\
11 \\
30 \\
\end{array}$ \\
\hline & & & & & & & Jumlah & 12.125 & 404 \\
\hline
\end{tabular}

Struktur rumah tangga penduduk di wilayah kepulauan ini sebagian besar antara $4-6$ orang selebihnya hanya terdiri dari 3 orang, dimana sebagian besar anggota keluarga berumur 15 - 59 tahun, Penghasilan rata-rata penduduk kepulauan Liukang Kalmas berkisar antara $1-3$ juta rupiah per bulan dengan tingkat pengeluaran $1-2$ juta per bulan. Dimana penghasil keluarga sebagian besar dihabiskan untuk pemenuhan kebutuhan harian dan untuk biaya sekolah.
- Kecamatan Liukang Tangayya

Potensi pergerakan penumpang diperoleh dengan melakukan survey pada pulau Sailus dan Sapuka yang merupakan hub pergerakan dalam wilayah ini. Berdasarkan hasil analisis Kategori, diperoleh bangkitan pergerakan pada kedua pulau tersebut. Untuk bangkitan pergerakan tiap pulau dalam wilayah administratif Kecamatan Liukang Tangayya dilakukan dengan pendekatan prosentasi jumlah penduduk dikarenakan keterbatasan waktu survey.

Tabel 7. Potensi bangkitan pergerakan tiap kelurahan di Kecamatan Liukang Tangayya

\begin{tabular}{|c|c|c|c|c|c|c|c|c|}
\hline No. & $\begin{array}{c}\text { Desa / } \\
\text { Kelurahan }\end{array}$ & $\begin{array}{l}\text { Luas } \\
\left(\mathbf{k m}^{2}\right)\end{array}$ & $\begin{array}{c}\text { Jarak ke } \\
\text { Ibukota } \\
\text { Kecamatan } \\
(\mathbf{k m})\end{array}$ & $\begin{array}{c}\text { Jarak ke } \\
\text { Ibukota } \\
\text { Kabupaten } \\
(\mathbf{k m})\end{array}$ & $\begin{array}{l}\text { Jumlah } \\
\text { Penduduk } \\
\text { (jiwa) }\end{array}$ & $\begin{array}{l}\text { Kepadatan } \\
\text { Penduduk } \\
\left(\text { jiwa } / \mathbf{k m}^{2} \text { ) }\right.\end{array}$ & $\begin{array}{c}\text { Potensi } \\
\text { Pergerakan } \\
\text { per bulan }\end{array}$ & $\begin{array}{c}\text { Potensi } \\
\text { Pergerakan } \\
\text { per hari }\end{array}$ \\
\hline 1 & Sabalana & 20.4 & 174 & 291 & 4,978 & 244 & 1,626 & 54 \\
\hline 2 & $\begin{array}{l}\text { Balo- } \\
\text { Baloang }\end{array}$ & 13.2 & 113 & 244 & 3,537 & 267 & 1,156 & 39 \\
\hline 3 & Sabaru & 10.5 & 111 & 243 & 955 & 94 & 312 & 10 \\
\hline 4 & Sapuka & 14.2 & - & 302 & 5,247 & 369 & 1,714 & 57 \\
\hline 5 & Tampaang & 11.6 & 54 & 363 & 1,377 & 118 & 450 & 15 \\
\hline 6 & Sailus & 14.37 & 96 & 463 & 3,367 & 233 & 1,100 & 37 \\
\hline 7 & Satanger & 17.5 & 113 & 574 & 1,366 & 78 & 446 & 15 \\
\hline 8 & $\begin{array}{l}\text { Kapoposan } \\
\text { Bali }\end{array}$ & 10.4 & 132 & 594 & 888 & 85 & 290 & 10 \\
\hline \multirow[t]{2}{*}{9} & Paleonro & 7.83 & 100 & 500 & 991 & 127 & 324 & 11 \\
\hline & & & & & & & 7,419 & 247 \\
\hline
\end{tabular}


Tabel 8. Potensi bangkitan pergerakan tiap pulau di Kecamatan Liukang Tangayya

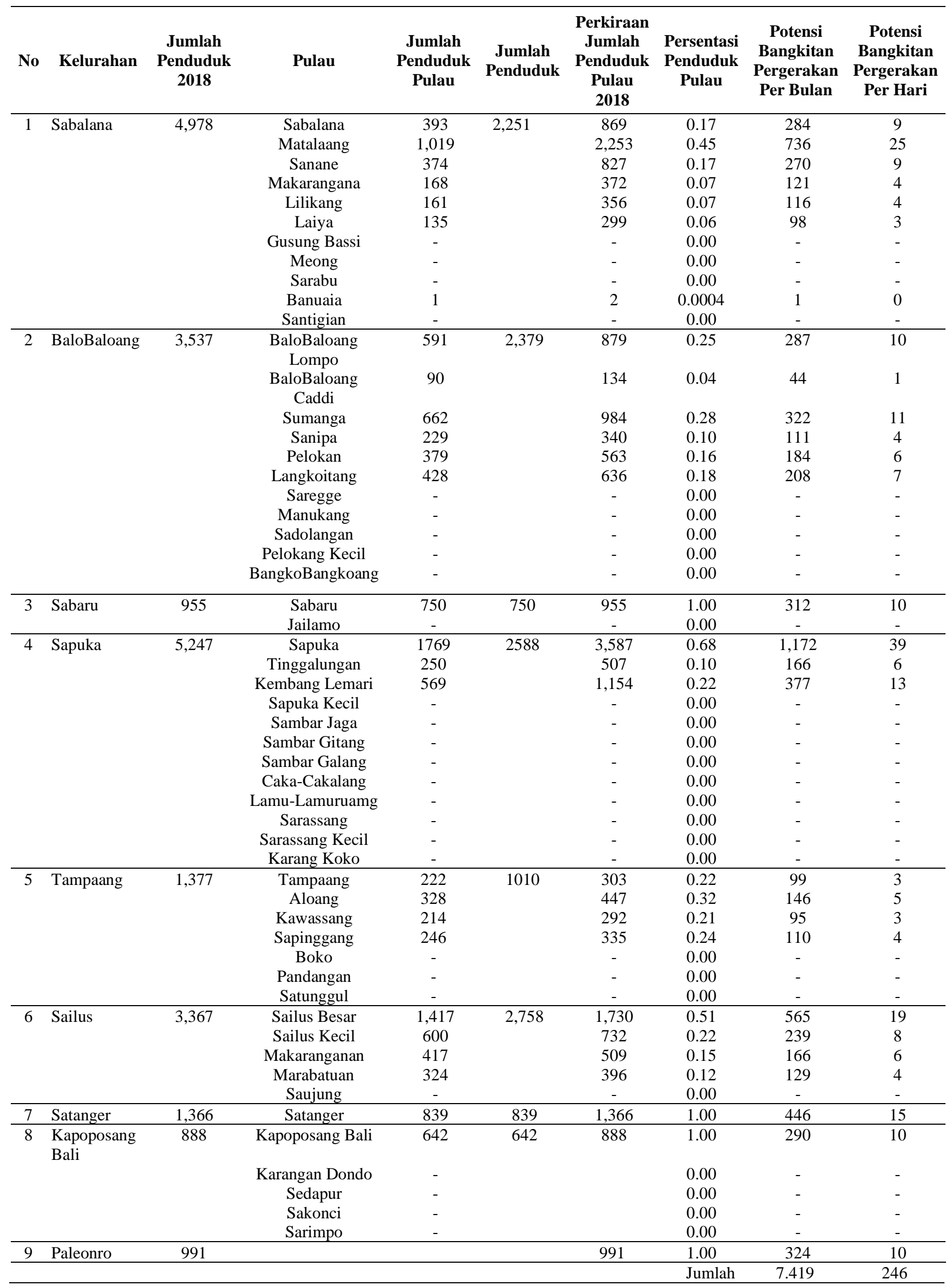


3.2.2 Model Jaringan Transportasi Gugus Pulau Kabupaten Pangkajene Kepulauan

Dari hasil analisis data bangkitan pergerakan di atas, teridentifikasi pulau-pulau yang memiliki potensi untuk dijadikan hub pada masing-masing gugus pulau, yaitu :

- Pada gugus pulau Liukang Tupabbiring adalah pulau Balang Lompo dan pulau Sarappo Lompo;

- Pada gugus pulau Liukang Tupabbiring Utara adalah pulau Gondong Bali dan pulau Sabutung;

- Pada gugus pulau Liukang Tangayya adalah pulau Matalaang, pulau Sapuka Lompo, dan pulau Sailus;

- Pada gugus pulau Liukang Kalmas adalah pulau Dewakang Lompo, pulau Kalukalukuang, dan pulau Pamantawang;

Adapun konektifitas jaringan-jaringan feeder dan pulau-pulau yang dijadikan hub adalah sebagai berikut :

- Gugus pulau Liukang Tuppabiring :

- Pulau Balang Caddi - Pulau Balang Lompo

- Pulau Bontosua - Pulau Sanane - Pulau Balang Lompo

- Pulau Badi - Pulau Pajenekang - Pulau Balang Lompo

- Pulau Sarappo Keke - Pulau Sarappo Lompo

- Pulau Pala - Pulau Sarappo Lompo

- Pulau Lamputang - Pulau Sarappo Lompo

- Pulau Podang-podang Lompo - Pulau Sarappo Lompo

- Gugus pulau Liukang Tuppabiring Utara :

- Pulau Kapoposang - Pulau Gondong Bali

- Pulau Pandangan - Pulau Gondong Bali

- Pulau Samatelu Lompo - Pulau Sabutung

- Pulau Salemo - Pulau Sabutung

- Pulau Polewali - Pulau Laiya - Pulau Kulambing - Pulau Sabutung

- Gugus pulau Liukang Tangayya :

- Pulau Sabaru Tangayya - Pulau Balobaloang Lompo - Pulau Balobaloang Kecil - Pulau Sumanga - Pulau Makaragana - Pulau Matalaang

- Pulau Lilikang - Pulau Sabalana - Pulau Sanane - Pulau Matalaang

- Pulau Pelokang - Pulau Matalaang
- Pulau Langkotang - Pulau Sanipa - Pulau Matalaang

- Pulau Kambang Lemari - Pulau Tinggalungan - Pulau Sapuka Lompo

- Pulau Kapoposang Bali - Pulau Satanger - Pulau Sailus Lompo

- Pulau Sailus Kecil - Pulau Sailus Lompo

- Pulau Tampaang - Pulau Pandangan Pulau Makarangan - Pulau Marabatuang - Pulau Sailus Lompo

- Pulau Kawassang - Pulau Sapinggan Pulau Aloang - Pulau Sailus Lompo

- Gugus pulau Liukang Kalmas :

- Pulau Bangkaluang - Pulau Dewakang Lompo

- Pulau Dewakkang Caddi - Pulau Dewakang Lompo

- Pulau Marsende - Pulau bangkobangkoang - Pulau Kalukalukuang

- Pulau Kanyurang - Pulau Kalukalukuang

- Pulau Sabaru - Pulau Masalima - Pulau Salirang - Pulau Pamantawang

- Pulau Pamolikang - Pulau Pamantawang

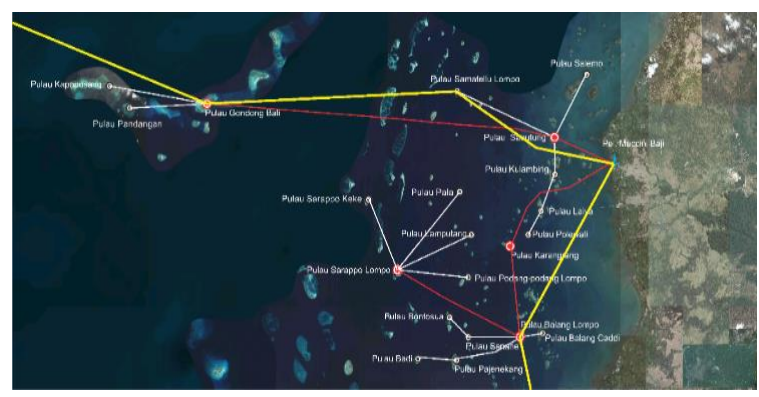

Gambar 1. Jaringan trayek angkutan laut gugus Liukang Tupabbiring dan Liukang Tupabbiring Utara

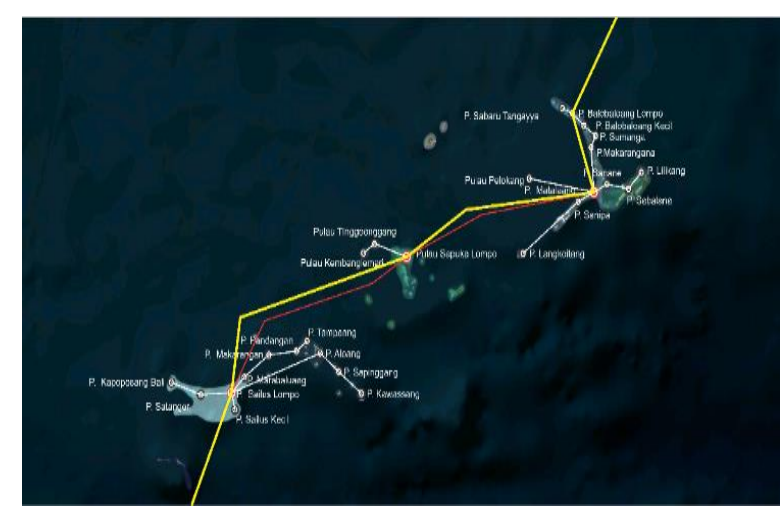

Gambar 2. Jaringan trayek angkutan laut gugus Liukang Tangayya 


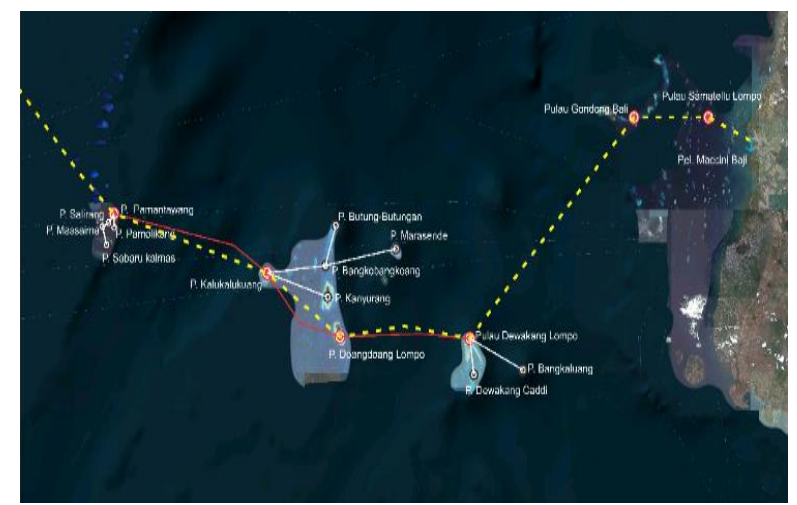

Gambar 3. Jaringan trayek angkutan laut gugus Liukang Kalmas

\section{Kesimpulan}

- Potensi bangkitan pergerakan penumpang di wilayah kepulauan sangat tinggi, namun ketersediaan jaringan dan pelayanan transportasi masih rendah;

- Penentuan hub pada masing-masing gugus pulau berdasarkan identifikasi potensi dan kondisi administratif (ibukota kecamatan), serta mempertimbangkan pulau-pulau yang masuk dalam Rencana Induk Pelabuhan Nasional;

- Sementara untuk hubungan masing-masing feeder ditentukan berdasarkan ukuran jarak dari/ke masing-masing hub.

\section{Referensi}

[1] http://pangkepkab.go.id/index.php.

[2] Nasution, H. M. N., 1996. Manajemen Transportasi. Ghalia Indonesia. Jakarta.

[3] Nasution, H. M. N., 2003. Metode Research. PT. Bumi Aksara. Jakarta.

[4] Nasution, H. M. N., 2004. Metode Research: Penelitian Ilmiah. PT. Bumi Aksara. Jakarta.

[5] Tamin Ofyar, Z. 2000. Perencanaan dan Permodelan Transportasi. Bandung, Indonesia. Penerbit ITB.

[6] BPS. 2019. Kabupaten Pangkajene dan Kepulauan Dalam Angka 2019. Badan Pusat Statistik Pangkajene dan Kepulauan.

[7] BPS. 2018. Kabupaten Pangkajene dan Kepulauan Dalam Angka 2018. Badan Pusat Statistik Pangkajene dan Kepulauan.

[8] BPS. 2017. Kabupaten Pangkajene dan Kepulauan Dalam Angka 2018. Badan Pusat Statistik Pangkajene dan Kepulauan. 